\title{
IMPROVEMENT OF THE RHEOLOGICAL AND PHYSICAL PROPERTIES OF NON-FAT YOGURT USING MICROBIAL TRANSGLUTAMINASE, EXOPOLYSACCHARIDES PRODUCING CULTURE AND COMMERCIAL STABILIZERS
}

\author{
Dina A.M. Amer ${ }^{(1)}$, M.Y.A. El-Hawary(1)and M.A. El-Soda ${ }^{(2)}$ \\ (1) Department of Food science and Technology, Faculty of Agriculture, Tanta University, Egypt \\ (2) Department of Dairy science and Technology, Faculty of Agriculture, Alexandria University, \\ Egypt
}

Received: Sep. 24, $2017 \quad$ Accepted: Oct. 18, 2017

\begin{abstract}
The aim of this study was to improve the rheological, physical and organoleptic properties of non-fat yogurt using microbial Transglutaminase (MTGase), Exopolysaccharides producing culture (EPS) and two commercial stabilizers based on pectin and gelatin. Results showed that non-fat yogurt samples produced by textural impotents haven't significant differences with control full-fat yogurt sample in moisture content at fresh, while there were significant differences between these samples and control non-fat yogurt sample. Moisture content significantly decreased in all yogurt samples except in control full and non-fat yogurt samples after 10 days of storage period. Non-fat yogurt EPS sample had the highest percentage moisture content compared with control (full-fat and non-fat) yogurt samples and experimental non-fat yogurt (MTGase, commercial pectin and gelatin) samples throughout storage. Pro/D.M was higher in control non-fat yogurt, non-fat yogurt EPS and non-fat yogurt produced by commercial gelatin compared with non-fat yogurt (MTGase, commercial pectin) and full-fat yogurt samples at fresh. There were no significant differences in Fat /D.M \% between non-fat yogurt $\mathrm{C} 2$ and non-fat samples containing textural improvements, while there were significant differences between them and control full-fat yogurt C1 at fresh or during storage period. There were no significant differences in acidity among all treatments. Hardness was significantly lower in the EPS non-fat yogurt compared with the other treatments throughout storage period. The non-fat yogurt containing EPS producing culture and non-fat yogurt containing commercial stabilizers had a lower level springiness, Chewiness and gumminess than the full-fat yogurt sample and non-fat yogurt containing MTGase. Adhesiveness significantly increased during storage period for all treatments. There were no significant differences in syneresis percentage among all treatments. Non-fat yogurt produced by Exopolysaccharides producing culture, microbial Transglutaminase and commerial gelatindemonstrated rheological and physical properties were closer to that of control full-fat yogurt.
\end{abstract}

Key words: MTGase, EPS, Pectin, Gelatin, Non-fat yogurt.

\section{INTRODUCTION}

Low fat and non-fat dairy products have gained popularity because of consumer awareness about health concerns related to decreasing the risks connected with obesity and coronary heart diseases (Sandoval et al., 2004). However, the partial or total removal of fat from dairy products decreases the overall quality perceived by the consumers (Folkenberg and Martens, 2006).
It was reported that reduction of fat content in dairy products resulted in lower gel strength and firmness than full fat products, as a consequence of lower number of fat globules embedded in the protein network (Duboc and Mollet, 2001).

To improve textural and functional properties of non-fat yogurt the use of additives has been widely investigated 
(Cayot et al., 2007). Fat replacers can be successfully used in the manufacture of reduced fat dairy products such as cheese, ice cream and yogurt (Barrantes et al., 1994). Fat replacer is an ingredient that can be used to provide some or all of the function of fat, yielding fewer calories (Huygbaert et al., 1996), to solve some physical and textural problems originating from low-fat level in the dairy products.

Enzymatic cross-linking of protein by microbial Transglutaminase (MTGase) modifies the techno-functional properties of proteins and is reported as an innovative way of producing novel milk gels (Anema et al., 2005and Jaros et al., 2010). It catalyzes the acyl-transfer (acyl donour) reaction between the $Y$-carboxyamid group of peptide or protein-bound glutaminyl residues and primary amines (acyl acceptor), is a transferees (Dickinson, Yamamoto, 1996 and Bonisch et al., 2007). Intermolecular cross-linking of proteins results in high molecular weight polymers which have different functional properties to improve the techno-functional properties of foods (Gauche et al., 2009, Lorenzen, et al., 2002 and Faergemand, \&Qvist, 1999). Milk proteins, especially caseins, are good substrates for cross-linking with MTGase (Faergemand, and Qvist, 1997 and Lorenzen, Schlimme, 1998). It was reported that cross-linking of the proteins in milk improved gels firmness and reduced serum separation of acid-induced milk gel, mainly set-type yogurts (Lorenzen,et al., 2002, Lorenzen,\& Schlimme, 1998 and Şanlı, et al., 2011). (Özer et al., 2007) also expressed that the MTGase added into milk may be an alternative method instead of addition of extra protein and stabilizer in non-fat yogurt.

Exopolysaccharides (EPS)-producing culture are used to modify texture of yogurt (Hassan, Frank, Schmidt, \& Shalabi, 1996a; Hassan \& Frank, 1997; Perry, McMahon, \& Oberg, 1997, 1998). Yogurt made with EPSproducing cultures is less susceptible to syneresis, more viscous, and had more water holding capacity than that made with EPS-non-producing cultures (Hassan, Frank, Schmidt, \& Shalabi, 1996a, b). The use of EPS-producing cultures produces soft cheese curd (Hassan \& Frank, 1997) and higher water retention in Mozzarella cheese (Perry et al., 1997, 1998 and Hassanet al., 2003).

Results obtained by (Fiszman et al., 1999) demonstrated the suitability of using of gelatin to improve the quality of milk products. Addition of gelatin to the milk during preparation of the yogurt changed the microstructure of the product by the formation of flat sheets or surfaces which interacted with the casein matrix, enclosing granules of casein in several zones. Gelatin seemed to connect the granules and chains of milk proteins, and consequently create a continuous, fairly homogeneous double network structure with no free ends. This more interconnected network would retain the aqueous phase more efficiently, reducing the drainage of liquid.

Pectin is a component of the primary cell wall of higher plants. It consists of polymers of D-a- $(1 \rightarrow 4)$ anhydro-galacturonic acid (at least $65 \%$ ) with a variable numbers of methyl ester groups (Wosiacki 1977). Pectins are divided into two categories depending on the degree of esterification: pectins with a degree of methylation $>50 \%$ are described as high-methoxyl pectins (HMP) whereas pectins with a degree of methylation $<50 \%$ are known as lowmethoxyl pectins (LMP) (Lootens et al. 2003; Tsoga et al. 2004). The degree of esterification can strongly influence the gel network of pectin (Sato et al. 2004). Highmethoxyl pectins can be obtained from citrus peels and apple pomace and is used as stabilizer, especially in acidic products, for example yogurt and acidic milk beverages. LMP can be obtained from citrus peels and is used as a gelling or thickening agent in acidic or less acidic products such as milk desserts (Williams and Phillips 2000 and Leroux et al. 2003). 
The objectives of this study was to investigate the possibility of making a good quality non-fat yogurt by using textural improvements: Microbial Transglutaminase (MTGase), Exopolysaccharides producing culture (EPS), commercial pectin and commercial gelatin and to monitor the changed yogurt quality during storage period.

\section{MATERIALS AND METHODS Materials}

Fresh full-fat and skim cow's milk was obtained from the farm of Faculty of Agriculture, Alexandria University. Skim milk powder (SMP) was obtained from Rucker Company, Germany.

Starter cultures, Freeze-dried lactic culture for direct vat set (DVS). (Express 0.2, thermophilic yogurt culture Yo-Flex Express), consisting of Lactobacillus delbrueckii ssp. bulgaricus and Streptococcus thermophilus was obtained from Chr. Hansen Lab., Denmark

\section{Textural improvements:}

Microbial Transglutaminase (MTGase): The $\mathrm{Ca}+2$-independent microbial Transglutaminase from Streptoverticulum mobaraense (Activa $\AA$ YG) was supplied from Ajinomoto Foods Europe (Hamburg, Germany) with concentration $0.02 \%(\mathrm{w} / \mathrm{w})$, Exopolysaccharides producing culture (EPS): The strain Lactobacillus delbrueckii ssp. Lactis 127ST used in this study was isolated from traditional fermented milk in the Laboratory of the Biochemistry of Dairy microorganisms, Alexandria University (Egypt) with concentration 1\% (v/v).

\section{The commercial stabilizer,}

Lacta 534 (based on gelatin E 441, Modified starch E 1422, Agar E 406 and Mono-and diglycerides E471) with concentration of $0.4 \%(\mathrm{w} / \mathrm{w})$.

Lacta 533 (based on pectin E 440, Modified starch E 1422, and Mono-and diglycerides E471) with concentration of
$0.4 \%(\mathrm{w} / \mathrm{w})$ were obtained from MIFAD Company, Alexandria, Egypt.

Chemicals used for the detecting of the fat, protein, etc., were obtained from ElGomhoria Company for chemicals and glasses.

\section{Yogurt Manufacture:}

Fresh full fat and skim cow's milk was fortified with $3 \%$ and $3.5 \%$ skim milk powder respectively and the stabilizers were added individually. The control 1 was full fat milk ( $3 \%$ fat, $13.2 \%$ TS), while the control 2 was non-fat milk $(0.4 \%$ fat, $10.21 \%$ TS) without adding stabilizers adding. Microbial Transglutaminase was added at $0.02 \%$, while Exopolysaccharides producing culture (EPS) was add at $1 \% \mathrm{v} / \mathrm{v}$. Yogurt was manufactured according to the protocol proposed by (Tamime and Robinson, 1999).

Individual milk samples were heat treated at $90^{\circ} \mathrm{C}$ for $10 \mathrm{~min}$, cooled to $42^{\circ} \mathrm{C}$ and inoculated with yogurt culture at the rate recommended by suppliers, incubation at $42^{\circ} \mathrm{C}$ till the $\mathrm{pH}$ reaching 4.9. This was followed by fast cooling to $7^{\circ} \mathrm{C}$ keeping the product at the same temperature overnight to represent fresh samples yogurt that were stored at $7 \pm 1^{\circ} \mathrm{C}$ for 10 days.

Commercial stabilizers based for gelatin and pectin were added before heat treatment, but Microbial Transglutaminase (MTGase) and Exopolysaccharides producing culture (EPS) were added with the addition of yogurt starter culture after heat treatment and cooling.

\section{Methods of analysis:}

Sampling: Yogurt samples were taken from the (fresh, 5 days and 10 days).

\section{Chemical analysis:}

All samples were analyzed for fat, total protein and dry matter according to A.O.A.C. (2000).

All samples were analyzed for acidity and $\mathrm{pH}$ according to Ling (1963). 


\section{Syneresis:}

The syneresis \% of yogurt samples was determined during storage period using centrifugation method as described by (Keogh and O'Kennedy, 1998). Yogurt (30$40 \mathrm{~g}$ ) was centrifuged at 1100 r.p.m. for 10 $\min$ at $5^{\circ} \mathrm{C}$. The clear supernatant was poured off, weighed and recorded as syneresis (\%). Duplicate measures were performed for each sample. Syneresis\% = (weight of supernatant /weight of yogurt sample) $\times 100$.

\section{Textural analysis:}

Textural properties of yogurt were evaluated using a texture analyzer (FTC TMS-Pro), USA). Yogurt samples were evaluated in their cups). A two-bite penetration test was performed using the Texture Analyzer with the TA $25 \mathrm{~mm}$ diameter cylinder probe for yogurt and operated at a crosshead speed $50 \mathrm{~mm} / \mathrm{sec}$. Hardness, cohesiveness, springiness and chewiness were evaluated in triplicate as described by Szczesniak et al (1963) and Bourne, (1978).

\section{Sensory evaluation:}

Sensory evaluation of yogurt samples was conducted by panelists. The panel lists were asked to evaluate the color (10), appearance (10), texture (35) and flavor (45) and overall acceptability when fresh, after 7 days and 10 days of storage according to Farag et al., (2007).

\section{Scanning electron microscopy:}

Samples of yogurt were fixed in $2.5 \%$ glutaraldehyde in cacodylate buffer $(\mathrm{pH} 7.2)$ for at least $1 \mathrm{~h}$. After rinsing three times in cacodylate buffer, samples were postfixed in a $1 \%$ buffered osmium tetroxide for one hour. The fixed samples were dehydrated using a graded alcohol series (20\%, 40\%, $60 \%, 70 \%$, and $90 \%$ ) finishing with three changes of $100 \%$ alcohol then critical point dried from liquid $\mathrm{Co}_{2}$. At least three dried samples of each yogurt were fractured, mounted on aluminum stubs, and coated with gold in a K550X sputter coater (England) as described by (Puvanenthiran et al., 2002). At least two images of typical structures at $1000 \times$ magnification were recorded using a Scanning Electron Microscope (JEOL JSM-5300 Scanning Microscope) by electron microscope Unite, Faculty of Science, Alexandria University.

\section{Statistical analysis:}

Data were analyzed as means, stander deviation and Duncan's test and subject to IBM SPSS version 16 Statistics for analysis of variance (ANOVA).

\section{RESULTS AND DISCUSSION 1. Chemical analysis}

Data in Table (1) showed moisture content \%, fat content/dry matter (F/DM) and total protein content/dry matter (Pro/DM). The obtained results showed that there were no significant differences between control full-fat yogurt $\mathrm{C} 1$ and non-fat yogurt containing textural improvements at fresh in moisture content, while there were significant differences between control nonfat yogurt C2 and all experimental treatments. During storage period moisture $\%$ significantly decreased in all samples except in $\mathrm{C} 1$ and $\mathrm{C} 2$. Also results showed that control full-fat yogurt had lower moisture\% compared with other samples, while control non-fat yogurt had highest moisture\%. Using different textural improvement had increase moisture\% than control non-fat yogurt. Non-fat yogurt produced by EPS had the highest moisture content compared with $\mathrm{C} 1, \mathrm{C} 2$ and all experimental samples after 10 days. These results are in agreement with JimenezGuzman et al. (2009), Trancoso-Reyes et al. (2014) who mentioned that EPS producing cultures have excellent water binding properties and moisture retention, which improve the quality of low fat dairy products. Also results showed non-fat yogurt made with lacta 533 based on pectin and lacta 534 based on gelatin reduce moisture\% when 


\begin{tabular}{|c|c|c|c|c|c|c|c|c|c|}
\hline \multirow{9}{*}{ 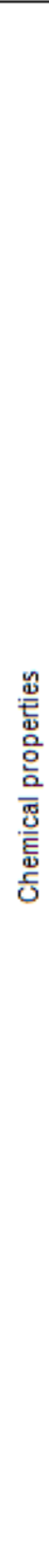 } & \multirow{3}{*}{$\begin{array}{l}\sum_{0} \\
\text { 음 }\end{array}$} & $\begin{array}{l}\text { 궁 } \\
\text { 음 } \\
\text { 은 }\end{array}$ & 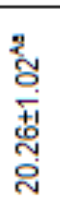 & 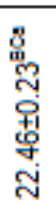 & 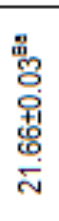 & 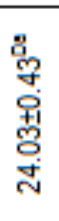 & 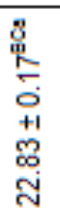 & 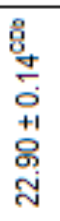 & \multirow{10}{*}{ 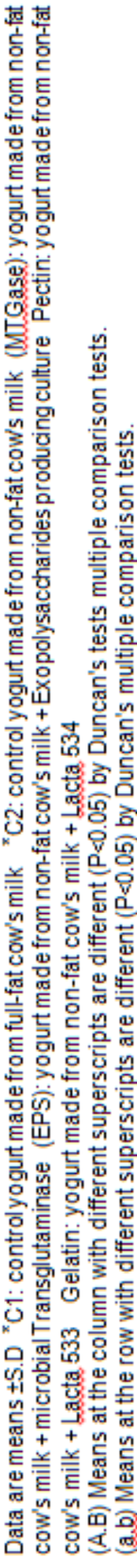 } \\
\hline & & $\begin{array}{l}\text { 齐 } \\
\text { 离 }\end{array}$ & 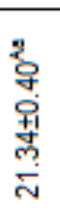 & 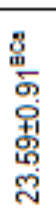 & 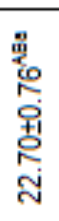 & 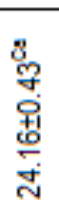 & 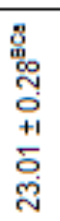 & 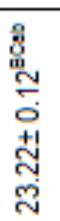 & \\
\hline & & $\begin{array}{l}\text { जू } \\
\text { 总 }\end{array}$ & 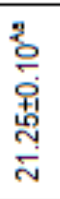 & 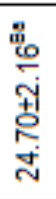 & 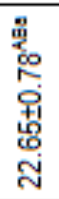 & 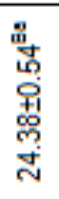 & 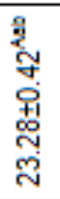 & 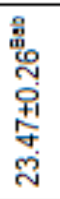 & \\
\hline & & $\begin{array}{l}\text { 슴 } \\
\text { 离 } \\
\text { 은 }\end{array}$ & 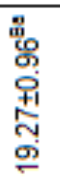 & $\begin{array}{l}\frac{2}{2} \\
\text { 웅 } \\
\text { 웡 } \\
0 \\
0\end{array}$ & 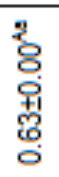 & 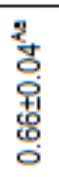 & 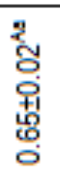 & 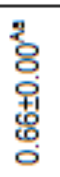 & \\
\hline & 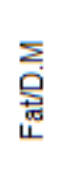 & $\begin{array}{l}\text { 先 } \\
\text { 离 } \\
\text { ம }\end{array}$ & 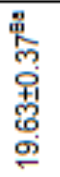 & 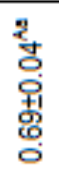 & 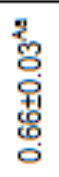 & $\begin{array}{l}\frac{2}{2} \\
\text { o } \\
\text { +1 } \\
\frac{1}{2} \\
0\end{array}$ & \begin{tabular}{l}
3 \\
웅 \\
+1 \\
\multirow{1}{0}{} \\
$\circ$ \\
0
\end{tabular} & 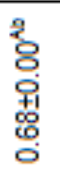 & \\
\hline & & $\begin{array}{l}\text { 员 } \\
\text { 这 }\end{array}$ & 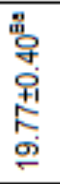 & 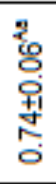 & $\begin{array}{l}3 \\
8 \\
0 \\
+1 \\
0 \\
0 \\
0\end{array}$ & \begin{tabular}{l}
$\frac{2}{2}$ \\
ơ \\
+1 \\
\multirow{2}{*}{} \\
0
\end{tabular} & 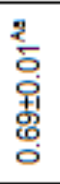 & 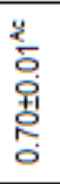 & \\
\hline & ळ & $\begin{array}{l}\text { 음 } \\
\text { 음 } \\
\text { 은 }\end{array}$ & 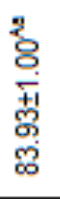 & 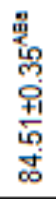 & 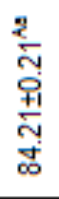 & 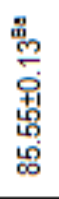 & 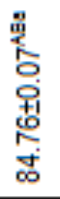 & 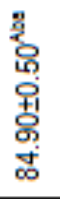 & \\
\hline & 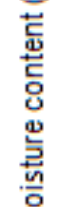 & 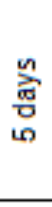 & 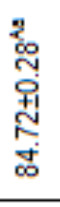 & 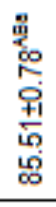 & 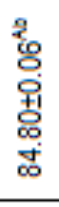 & 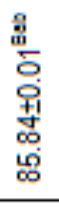 & 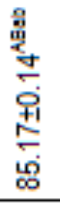 & 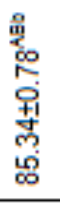 & \\
\hline & $\Sigma$ & $\begin{array}{l}\text { 员 } \\
\text { 这 }\end{array}$ & 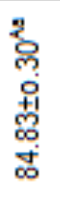 & 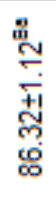 & 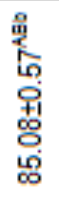 & 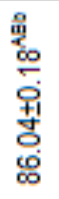 & 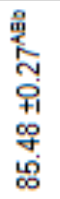 & 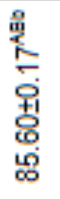 & \\
\hline 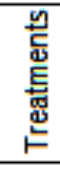 & & & $\overline{0}$ & $\widetilde{\delta}$ & 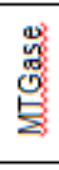 & 㞻 & $\begin{array}{l}\text { 离 } \\
\text { 总 }\end{array}$ & $\begin{array}{l}\text { 点 } \\
\frac{\text { w }}{\mathrm{d}} \\
0\end{array}$ & \\
\hline
\end{tabular}


compared to control non-fat yogurt C2 at fresh. These Results are in agreement with Yazici and Akgun (2004) who found that some protein based fat replacers in low fat yogurt led to an increase in dry matter. Total solids contents were found to be higher in yogurts with stabilizers, compared with control yogurts reflecting higher total solids content in treated yogurts due to addition of stabilizers (Mehanna, et al., 2013) Changes in this parameters may affect certain other physico-chemical properties such as syneresis, water holding capacity $(\mathrm{Wu}$, et al., 2001). There were significant difference in Pro/D.M between controls $\mathrm{C} 1, \mathrm{C} 2$ and samples containing textural improvements at fresh and after 10 days of storage period. Pro/ D.M was higher in control non-fat C2, non-fat yogurt produced by EPS and non-fat yogurt produced by commercial gelatin compared with control full-fat yogurt $\mathrm{C} 1$ and other experimental samples at fresh. After 10 days non-fat yogurt EPS had the highest Pro/D.M compared with all experimental treatments. Control full-fat yogurt had lowest Pro/D.M, compared with all experimental treatments after 10 days. There were no significant differences in Fat /D.M\% between non-fat yogurt $\mathrm{C} 2$ and non-fat samples containing textural improvements, while there were significant differences between them and control full-fat yogurt $\mathrm{C} 1$ at fresh or during storage period.

\section{2- Acidity\% and $\mathrm{pH}$ value}

Fresh yogurt controls (full-fat and non-fat) had similar acidity levels. While, the acidity was at high level in fresh treatments with commercial (pectin, gelatin)and EPS but was low in treatment with MTGase(Table 2).The acidity wasn't significantly increased during storage in all samples expect in yogurt produced by MTGase had increased at the end of storage period. There were no significant differences in $\mathrm{pH}$ value between all samples. While the $\mathrm{pH}$ value was lower in non-fat yogurt that contains EPS. There was no significant variation $(\mathrm{P}>0.05)$ in $\mathrm{pH}$ value of non-fat yogurt that containing textural improvements throughout storage period. During storage period, all non-fat yogurt samples showed gradual decrease in $\mathrm{pH}$ until the end of storage period. These findings are in good agreement with (Lorenzen et al.,2002). Also these results are in agreement with those obtained by (Anis et al., 1989) and Mehanna (1989); Abd El-salam et al., (1996) who studied the use of textural improvement to improve some properties of skim cow's milk yogurt and showed that Titratable acidity of all yogurt treatments increased significantly as storage period was progressed.

\section{3- Texture analysis}

Rheological properties for foods, such as fermented dairy products, are important in the design of flow processes, quality control, storage and processing and in predicting the texture of foods (Shaker et al., 2000). Table (3) shows the texture parameters (Hardness, Adhesiveness, Cohesiveness, Springiness, Chewiness and Gumminess) of the different treatment of yogurt over storage. The Hardness of yogurt is directly dependent on its total solids and specifically protein content and the type of proteins. Higher protein content would cause a higher degree of cross-linkage of the gel network, resulting in a much denser and more rigid gel structure (Tamime 2006). Hardness was significantly lower in the EPS non-fat yogurt compared with the other treatments throughout storage. This coincides with the lower intact casein content of the EPS yogurt as a consequence of its higher levels of moisture content. At the same time, the presence of the EPS within the yogurt matrix may also have helped to reduce the hardness by filling voids in the matrix and by interacting with the proteins. The non-fat yogurt containing EPS producing culture and non-fat yogurt containing stabilizers had a lower level springiness than the full fat yogurt and non-fat yogurt containing MTGase, an effect that may be attributed to the higher content of intact casein and higher moisture content. Many researchers 
reported that the Exopolysaccharides could improve the texture of yogurt, because Exopolysaccharides produced by LAB interacts with the free water in the gel-like structure (Guzel et al., 2005, De Vuyst and Degeest 1999, Hassan et al., 2003). Chewiness and gumminess were significantly lower in non-fat yogurt containing EPS producing culture and nonfat yogurt containing stabilizers in compared with full-fat yogurt and non-fat yogurt containing MTGase. Yogurt hardness correlated positively with Chewiness and gumminess. Adhesiveness significantly increased during storage for all treatments. No significant differences were detected in cohesiveness, the increase in the moisture content in the non-fat yogurt containing EPS producing culture and non-fat yogurt contain stabilizers had little effect on the cohesiveness of the yogurt.

Table (2): Acidity (\%) and pH value of non-fat yogurt made with textural improvements at fresh and during the storage periods

\begin{tabular}{|c|c|c|c|}
\hline \multirow{2}{*}{ Treatments } & \multicolumn{3}{|c|}{ Acidity (\%) } \\
\cline { 2 - 4 } & Fresh & 5 days & 10 days \\
\hline C1 & $0.87 \pm 0.01^{\mathrm{Aa}}$ & $0.89 \pm 0.01^{\mathrm{Aa}}$ & $0.89 \pm 0.01^{\mathrm{Aa}}$ \\
\hline C2 & $0.84 \pm 0.06^{\mathrm{Aa}}$ & $0.89 \pm 0.10^{\mathrm{Aa}}$ & $1.01 \pm 0.01^{\mathrm{Aa}}$ \\
\hline MTGase & $0.74 \pm 0.03^{\mathrm{Aa}}$ & $0.81 \pm 0.01^{\mathrm{Aa}}$ & $0.99 \pm 0.04^{\mathrm{Aa}}$ \\
\hline EPS & $0.95 \pm 0.18^{\mathrm{Aa}}$ & $1.00 \pm 0.25^{\mathrm{Aa}}$ & $1.10 \pm 0.25^{\mathrm{Aa}}$ \\
\hline Pectin & $1.04 \pm 0.14^{\mathrm{Aa}}$ & $0.87 \pm 0.78^{\mathrm{Aa}}$ & $0.84 \pm 0.36^{\mathrm{Aa}}$ \\
\hline Gelatin & $1.01 \pm 0.42^{\mathrm{Aa}}$ & $0.84 \pm 0.42^{\mathrm{Aa}}$ & $0.91 \pm 0.07^{\mathrm{Aa}}$ \\
\hline Treatments & \multicolumn{3}{|c|}{$\mathrm{pH}$ value period } \\
\cline { 2 - 4 } & Fresh & 5 days & 10 days \\
\hline C1 & $4.71 \pm 0.09^{\mathrm{Aa}}$ & $4.64 \pm 0.35^{\mathrm{Aa}}$ & $4.36 \pm 0.42^{\mathrm{Aa}}$ \\
\hline C2 & $4.79 \pm 0.78^{\mathrm{Aa}}$ & $4.73 \pm 0.07^{\mathrm{Aa}}$ & $4.53 \pm 0.15^{\mathrm{Aa}}$ \\
\hline MTGase & $4.74 \pm 0.22^{\mathrm{Aa}}$ & $4.62 \pm 0.13^{\mathrm{Aa}}$ & $4.48 \pm 0.27^{\mathrm{Aa}}$ \\
\hline EPS & $4.59 \pm 0.52^{\mathrm{Aa}}$ & $4.45 \pm 0.36^{\mathrm{Aa}}$ & $4.40 \pm 0.55^{\mathrm{Aa}}$ \\
\hline Pectin & $4.66 \pm 0.13^{\mathrm{Aa}}$ & $4.63 \pm 0.14^{\mathrm{Aa}}$ & $4.50 \pm 0.25^{\mathrm{Aa}}$ \\
\hline Gelatin & $4.56 \pm 0.23^{\mathrm{Aa}}$ & $4.73 \pm 0.14^{\mathrm{Aa}}$ & $4.70 \pm 0.16^{\mathrm{Aa}}$ \\
\hline
\end{tabular}

Data are means $\pm S . D{ }^{*} \mathrm{C} 1$ : control yogurt made from full-fat cow's milk ${ }^{*} \mathrm{C} 2$ : control yogurt made from non-fat cow's milk (MTGase): yogurt made from non-fat cow's milk + microbial Transglutaminase (EPS): yogurt made from non-fat cow's milk + Exopolysaccharides producing culture Pectin: yogurt made from non-fat cow's milk + Lacta 533 Gelatin: yogurt made from non-fat cow's milk + Lacta 534

(A.B) Means at the column with different superscripts are different $(P<0.05)$ by Duncan's tests multiple comparison tests.

(a.b) Means at the row with different superscripts are different $(P<0.05)$ by Duncan's multiple comparison tests 
Dina A.M. Amer, et al.,

Table (3): Texture analysis of non-fat yogurt made with textural improvements at fresh and during the storage periods

\begin{tabular}{|c|c|c|c|c|c|c|c|}
\hline \multirow[t]{2}{*}{ Texture properties } & \multirow{2}{*}{$\begin{array}{l}\text { Storage } \\
\text { period }\end{array}$} & \multicolumn{6}{|c|}{ Treatments } \\
\hline & & C1 & $\mathrm{C} 2$ & MTGase & EPS & Pectin & Gelatin \\
\hline \multirow[t]{3}{*}{ Hardness (g) } & Fresh & 134 & 112.50 & 154.50 & 103.50 & 106 & 113 \\
\hline & 5 days & 138 & 121.00 & 200.00 & 101.50 & 110.50 & 112.50 \\
\hline & 10 days & 140 & 123.50 & 174.00 & 99.50 & 110.50 & 110.50 \\
\hline \multirow{3}{*}{$\begin{array}{l}\text { Adhesiveness } \\
\text { (g.mm) }\end{array}$} & Fresh & 98.30 & 95.73 & 154.50 & 103.70 & 105.36 & 104 \\
\hline & 5 days & 109.90 & 94.48 & 94.47 & 92.33 & 111.28 & 111.11 \\
\hline & 10 days & 119.68 & 97.18 & 101.85 & 92.22 & 96.42 & 96.86 \\
\hline \multirow[t]{3}{*}{ Adhesive force $(\mathrm{g})$} & Fresh & -31.50 & -23.50 & -23.50 & -20.50 & -23 & -23 \\
\hline & 5 days & -29.50 & -29.00 & -30.50 & -25.50 & 27.50 & 27.50 \\
\hline & 10 days & -27.00 & -28.00 & -30.50 & -24.50 & 27 & 27 \\
\hline \multirow[t]{3}{*}{ Cohesiveness } & Fresh & 0.42 & 0.40 & 0.36 & 0.40 & 0.40 & 0.40 \\
\hline & 5 days & 0.41 & 0.38 & 0.32 & 0.36 & 0.40 & 0.43 \\
\hline & 10 days & 0.30 & 0.38 & 0.37 & 0.41 & 0.38 & 0.38 \\
\hline \multirow[t]{3}{*}{ Springiness (m.m) } & Fresh & 6.37 & 5.36 & 5.47 & 5.70 & 5.60 & 5.59 \\
\hline & 5 days & 6.91 & 5.70 & 6.03 & 5.62 & 6.02 & 6.15 \\
\hline & 10 days & 7.15 & 5.67 & 5.92 & 5.72 & 5.95 & 5.82 \\
\hline \multirow[t]{3}{*}{ Chewiness (mJ) } & Fresh & 350.40 & 2.40 .90 & 300.50 & 235.01 & 236.86 & 252.63 \\
\hline & 5 days & 389.68 & 262.16 & 386.31 & 222.08 & 279.76 & 269.93 \\
\hline & 10 days & 379.56 & 262.38 & 381.16 & 218.62 & 249.46 & 241.04 \\
\hline \multirow[t]{3}{*}{ Gumminess (N) } & Fresh & 55.50 & 45 & 55 & 41 & 42.50 & 45.25 \\
\hline & 5 days & 58.80 & 46 & 64 & 39.50 & 44 & 48 \\
\hline & 10 days & 53.50 & 48.50 & 64.50 & 38.00 & 42 & 41.50 \\
\hline
\end{tabular}

Data are means $\pm S . D{ }^{*} \mathrm{C} 1$ : control yogurt made from full-fat cow's milk ${ }^{*} \mathrm{C} 2$ : control yogurt made from non-fat cow's milk (MTGase): yogurt made from non-fat cow's milk + microbial Transglutaminase (EPS): yogurt made from non-fat cow's milk + Exopolysaccharides producing culture Pectin: yogurt made from non-fat cow's milk + Lacta 533 Gelatin: yogurt made from non-fat cow's milk + Lacta 534

\section{Syneresis values:}

Serum separation occurs in fermented milk products due to the aggregation and sedimentation of casein particles during storage. Textural improvements were found to be necessary to prevent serum separation in fermented milk (Lucey et al., 1999;
Towler, 1984).Syneresis an undesirable property in yogurt products $(\mathrm{Wu}$, et al., 2001).

Values of syneresis was $22.55 \%$ in fresh non-fat yogurt, it was increased to $27.45 \%$ after 10 days throughout storage (Table 4). There were differences in syneresis value 
among all treatments samples at fresh or during storage period but these differences were not significantly. The Syneresis was lower in full-fat treatment when compared to non-fat counterpart. High fat content in yogurt has been associated with lower syneresis values (Keogh and O'Kennedy, 1998 and Isanga and Zhang, 2009). Common reasons for the occurrence of syneresis are low dry matter and protein contents. Enrichment of dry matter content is common way of avoiding syneresis (Amatayakul et al. 2006). Results reported that at fresh non-fat yogurt MTGase sample was lower in syneresis \% than controls (full and non-fat) yogurt and non-fat yogurt with stabilizers (commercial pectin, gelatin), although non-fat yogurt EPS sample was higher. This may due to the cross-linking of protein chains by microbial Transglutaminase (MTGase) can stabilize the three dimensional network of yogurt gel and decreased syneresis\% as a result of decrease whey expulsion as a result of decrease in gel porosity (Faergamand et al. 1999; özer et al., 2007; Sanli et al., 2011). Also these results were similar to (Folkenberg et al. 2003). Who reported that syneresis of yogurt made with EPSproducing cultures was higher than those made with non- EPS- producing cultures due to their water-binding ability and texture promoting properties (Amatayakul et al. 2006).

\section{Organoleptic properties:}

The results of the evaluation of different non-fat yogurts through 10 days of the storage period are shown in Table (5). Results indicated that there were no significant among all samples in color and appearance. The texture of yogurt made with commercial gelatin was firmer than (C1) and (C2). Addition of stabilizers, improved the Body \& Texture of the non-fat yogurt as compared with control non-fat yogurt to be similar with full fat control, non-fat yogurt produced by commercial gelatin had highest texture compared with all samples. Also results showed that flavor of all samples were improved by textural improvements as control full-fat yogurt compared with control non-fat yogurt. Color and appearance of the yogurt samples were scored most highly for treatment EPS and gelatin compared with MTGase and pectin.

Table (4): Syneresis (\%) of non-fat yogurt made with of textural improvements at fresh and during the storage periods

\begin{tabular}{|c|c|c|c|}
\hline \multirow{2}{*}{ Samples } & \multicolumn{3}{|c|}{ Storage periods } \\
\cline { 2 - 4 } & Fresh & 5 days & 10 days \\
\hline C1 & $17.25 \pm 2.36^{\mathrm{Aa}}$ & $20.08 \pm 1.05^{\mathrm{Aa}}$ & $18.91 \pm 4.55^{\mathrm{Aa}}$ \\
\hline C2 & $22.25 \pm 9.97^{\mathrm{Aa}}$ & $25.80 \pm 6.48^{\mathrm{Aa}}$ & $27.45 \pm 7.84^{\mathrm{Aa}}$ \\
\hline MTGase & $14.23 \pm 0.64^{4 a}$ & $23.32 \pm 3.56^{\mathrm{Aa}}$ & $24.50 \pm 2.82^{\mathrm{Ab}}$ \\
\hline EPS & $25.77 \pm 2.26^{\mathrm{Aa}}$ & $24.60 \pm 6.07^{\mathrm{Aa}}$ & $24.79 \pm 2.24^{\mathrm{Aa}}$ \\
\hline Pectin & $19.26 \pm 7.23^{\mathrm{Aa}}$ & $23.37 \pm 3.91^{\mathrm{Aa}}$ & $23.70 \pm 1.13^{\mathrm{Aa}}$ \\
\hline Gelatin & $16.79 \pm 7.96^{\mathrm{Aa}}$ & $22.72 \pm 1.01^{\mathrm{Aa}}$ & $22.60 \pm 0.14^{\mathrm{Aa}}$ \\
\hline
\end{tabular}

Data are means \pm S.D ${ }^{*} \mathrm{C} 1$ : control yogurt made from full-fat cow's milk ${ }^{*} \mathrm{C} 2$ : control yogurt made from non-fat cow's milk (MTGase): yogurt made from non-fat cow's milk + microbial Transglutaminase (EPS): yogurt made from non-fat cow's milk + Exopolysaccharides producing culture Pectin: yogurt made from non-fat cow's milk + Lacta 533 Gelatin: yogurt made from non-fat cow's milk + Lacta 534

(A.B) Means at the column with different superscripts are different $(P<0.05)$ by Duncan's tests multiple comparison tests.

(a.b) Means at the row with different superscripts are different $(P<0.05)$ by Duncan's multiple comparison tests 
Dina A.M. Amer, et al.,

Table (5): Organoleptic properties of non-fat yogurt made with different textural improvements at fresh and during storage periods

\begin{tabular}{|c|c|c|c|c|c|}
\hline Treatments & $\begin{array}{l}\text { Storage } \\
\text { period }\end{array}$ & $\begin{array}{c}\text { Appearance } \\
\text { (10) }\end{array}$ & $\begin{array}{l}\text { Color } \\
(10)\end{array}$ & $\begin{array}{c}\text { Texture } \\
\text { (35) }\end{array}$ & $\begin{array}{l}\text { Flavor } \\
(45)\end{array}$ \\
\hline \multirow[t]{3}{*}{ C1 } & Fresh & $9.50 \pm 0.71^{\mathrm{Aa}}$ & $9.00 \pm 0.00^{\mathrm{Aa}}$ & $32.50 \pm 0.71^{\mathrm{ABa}}$ & $43.50 \pm 0.7^{1 \mathrm{Ba}}$ \\
\hline & 5 days & $8.75 \pm 0.35^{\mathrm{Aa}}$ & $8.75 \pm 0.35^{\mathrm{Aa}}$ & $33.00 \pm 0.00^{\mathrm{ABa}}$ & $42.00 \pm 0.00^{\mathrm{Aa}}$ \\
\hline & 10 days & $9.50 \pm 0.71^{\mathrm{Aa}}$ & $9.50 \pm 0.71^{\mathrm{Aa}}$ & $32.50 \pm 0.71^{\mathrm{Aa}}$ & $42.50 \pm 0.71^{\mathrm{Aa}}$ \\
\hline \multirow[t]{3}{*}{$\mathrm{C} 2$} & Fresh & $9.25 \pm 0.35^{\mathrm{Aa}}$ & $9.00 \pm 0.00^{\mathrm{Aa}}$ & $31.50 \pm 0.71^{\mathrm{Aa}}$ & $39.50 \pm 0.71^{\mathrm{Aa}}$ \\
\hline & 5 days & $9.25 \pm 0.35^{\mathrm{Aa}}$ & $9.75 \pm 0.35^{\mathrm{Ba}}$ & $33.00 \pm 0.00^{\mathrm{ABb}}$ & $42.50 \pm 0.71^{\mathrm{Aa}}$ \\
\hline & 10 days & $9.50 \pm 0.71^{\mathrm{Aa}}$ & $9.50 \pm 0.71^{\mathrm{Aa}}$ & $33.00 \pm 0.00^{\mathrm{Ab}}$ & $40.00 \pm 1.41^{\mathrm{Aa}}$ \\
\hline \multirow[t]{3}{*}{ MTGase } & Fresh & $9.00 \pm 0.00^{\mathrm{Aa}}$ & $8.50 \pm 0.71^{\mathrm{Aa}}$ & $33.50 \pm 0.71^{\mathrm{BCa}}$ & $41.50 \pm 0.71^{\mathrm{ABa}}$ \\
\hline & 5 days & $9.50 \pm 0.71^{\mathrm{Aa}}$ & $9.75 \pm 0.35^{\mathrm{Aa}}$ & $34.50 \pm 0.71^{\mathrm{BCa}}$ & $43.50 \pm 0.71^{\mathrm{Ab}}$ \\
\hline & 10 days & $9.00 \pm 0.00^{\mathrm{Aa}}$ & $9.00 \pm 0.00^{\mathrm{Aa}}$ & $33.00 \pm 0.00^{\mathrm{Aa}}$ & $41.75 \pm 0.35^{\mathrm{Aab}}$ \\
\hline \multirow[t]{3}{*}{ EPS } & Fresh & $9.50 \pm 0.71^{\mathrm{Aa}}$ & $9.50 \pm 0.71^{\mathrm{Aa}}$ & $33.50 \pm 0.71^{\mathrm{BCa}}$ & $41.50 \pm 2.12^{\mathrm{ABa}}$ \\
\hline & 5 days & $9.50 \pm 0.71^{\mathrm{Aa}}$ & $9.00 \pm 0.00^{\mathrm{Aa}}$ & $34.00 \pm 0.00^{\mathrm{BCa}}$ & $42.00 \pm 0.00^{\mathrm{Aa}}$ \\
\hline & 10 days & $10.00 \pm 0.00^{\mathrm{Aa}}$ & $10.00 \pm 0.00^{\mathrm{Aa}}$ & $33.50 \pm 0.71^{\mathrm{Aa}}$ & $42.00 \pm 0.00^{\mathrm{Aa}}$ \\
\hline \multirow[t]{3}{*}{ Pectin } & Fresh & $9.00 \pm 0.00^{\mathrm{Aa}}$ & $9.00 \pm 1.41^{\mathrm{Aa}}$ & $32.50 \pm 0.71^{\mathrm{Aa}}$ & $41.00 \pm 1.41^{\mathrm{ABa}}$ \\
\hline & 5 days & $8.75 \pm 0.35^{\mathrm{Aa}}$ & $9.00 \pm 0.00^{\mathrm{Aa}}$ & $34.00 \pm 0.00^{\mathrm{Cb}}$ & $42.50 \pm 0.71^{\mathrm{Aa}}$ \\
\hline & 10 days & $9.00 \pm 0.00^{\mathrm{Aa}}$ & $9.00 \pm 0.00^{\mathrm{Aa}}$ & $32.25 \pm 0.35^{\mathrm{Aa}}$ & $42.00 \pm 0.00^{\mathrm{Aa}}$ \\
\hline \multirow[t]{3}{*}{ Gelatin } & Fresh & $10.00 \pm 0.00^{\mathrm{Aa}}$ & $10.00 \pm 0.00^{\mathrm{Aa}}$ & $34.00 \pm 0.00^{\mathrm{Ca}}$ & $42.50 \pm 0.71^{\mathrm{ABa}}$ \\
\hline & 5 days & $9.00 \pm 0.00^{\mathrm{Aa}}$ & $9.25 \pm 0.35^{\mathrm{ABa}}$ & $32.50 \pm 0.71^{\mathrm{Aa}}$ & $42.50 \pm 2.12^{\mathrm{Aa}}$ \\
\hline & 10 days & $9.00 \pm 0.00^{\mathrm{Aa}}$ & $9.00 \pm 0.00^{\mathrm{Aa}}$ & $32.25 \pm 1.06^{\mathrm{Aa}}$ & $42.50 \pm 2.12^{\mathrm{Aa}}$ \\
\hline
\end{tabular}

Data are means \pm S.D ${ }^{*} \mathrm{C} 1$ : control yogurt made from full-fat cow's milk ${ }^{*} \mathrm{C} 2$ : control yogurt made from non-fat cow's milk (MTGase): yogurt made from non-fat cow's milk + microbial Transglutaminase (EPS): yogurt made from non-fat cow's milk + Exopolysaccharides producing culture Pectin: yogurt made from non-fat cow's milk + Lacta 533 Gelatin: yogurt made from non-fat cow's milk + Lacta 534

(A.B) Means at the column with different superscripts are different $(P<0.05)$ by Duncan's tests multiple comparison tests.

(a.b) Means at the row with different superscripts are different $(\mathrm{P}<0.05)$ by Duncan's multiple comparison tests

\section{Microstructure}

It is well recognized that the structure of foods affects various properties including texture, functionality and appearance. Microstructure has a major impact on the texture and other physical properties of acid gels such as yogurt (Lee and Lucey 2010). The SEM images of the experimental materials can be seen in Fig (1, 2, 3, 4, 5and
6). The full-fat yogurt had large pore sizes with smaller strands of protein in the microstructure compared to other samples. Treated yogurts (MTGase, pectin, gelatin and EPS) had more systematically and smoothly distributed casein with a bit coarse structure as well as less porosity in casein network. This might be attributed to hydrocolloids and emulsion stability 
catalyzed cross-link formation between milk proteins as reported by (Lorenzen et al., (2002). Control of non-fat yogurt contained fewer and larger pores than yogurt made with the EPS-producing culture. It was observed that the protein matrix of yogurt made using EPS- producing starter had a more homogenous compared to control C1and C2. However MTGase sample, it was possible to obtain high gel strength owing to the reduced mesh size of the protein network. This is in agreement with the result of (Lorenzen et al. 2002 and Asaanli et al. 2011).

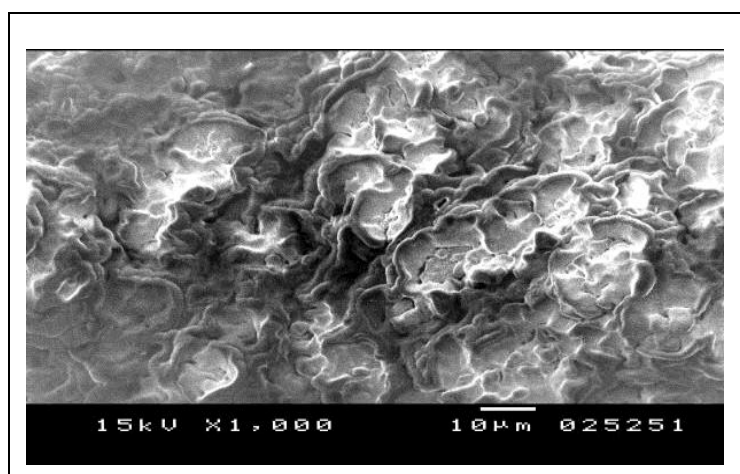

Fig. 1. Scanning electron microscopy photographs $(\times 1000)$ of control full-fat fresh yogurt.

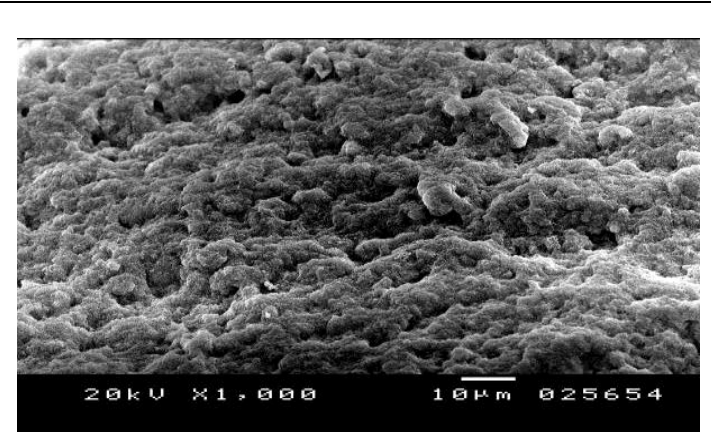

Fig. 2. Scanning electron microscopy photographs $(\times 1000)$ of control non-fat fresh yogurt.

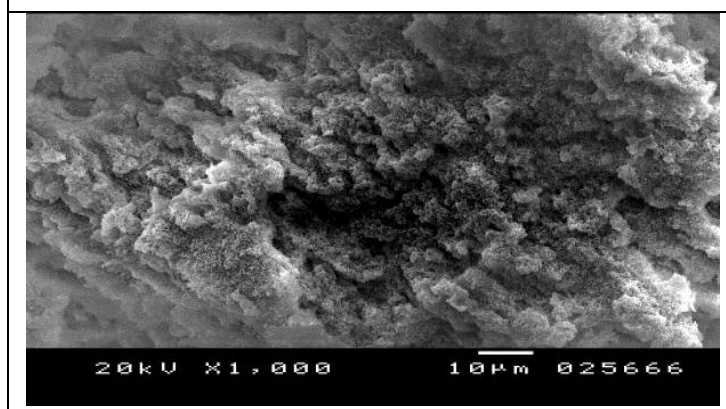

Fig. 3. Scanning electron microscopy photographs $(\times 1000)$ of control non-fat fresh yogurt with MTGase

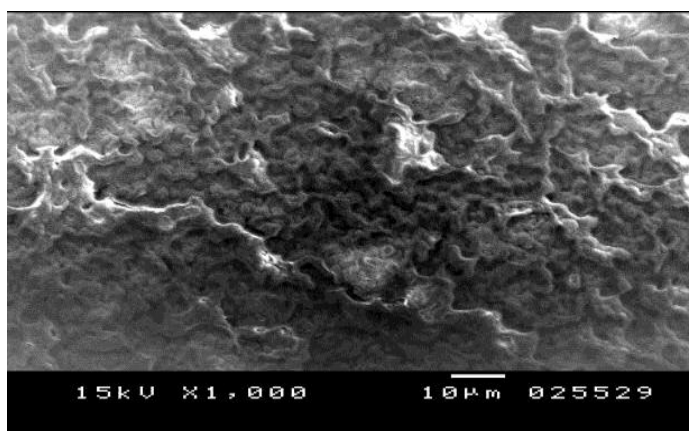

Fig. 1.1. Scanning electron microscopy photographs $(\times 1000)$ of control full-fat yogurt storage at 10 days.

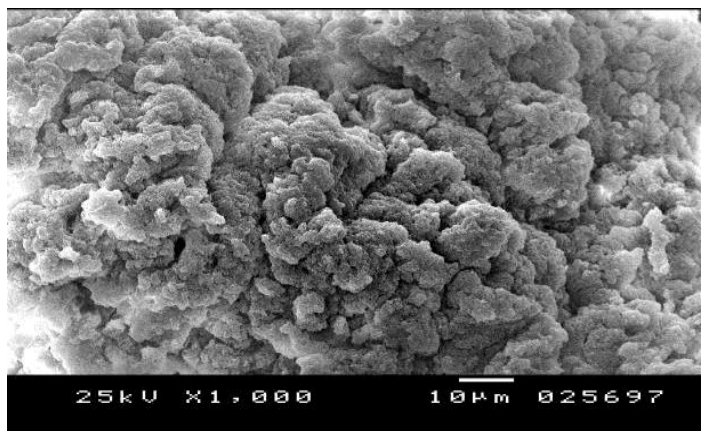

Fig. 2.2. Scanning electron microscopy photographs $(\times 1000)$ of control non-fat yogurt storage at 10 days.

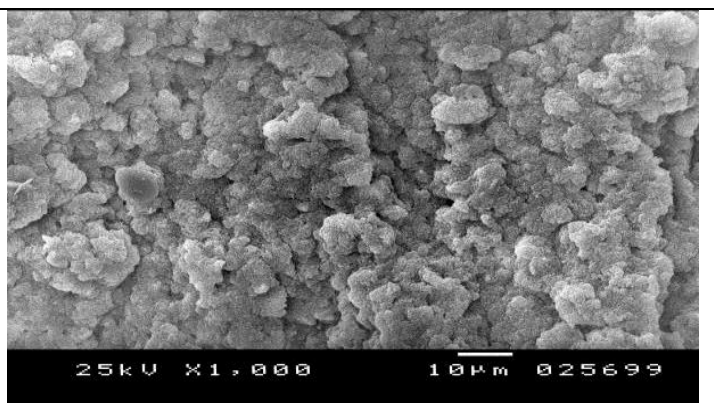

Fig. 3.3. Scanning electron microscopy photographs $(\times 1000)$ of control non-fat yogurt with MTGase storage at 10 days 


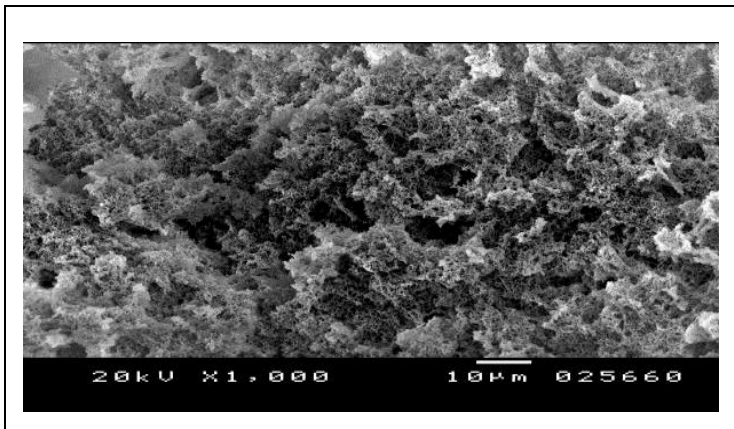

Fig. 4. Scanning electron microscopy photographs $(\times 1000)$ of control non-fat fresh yogurt with EPS

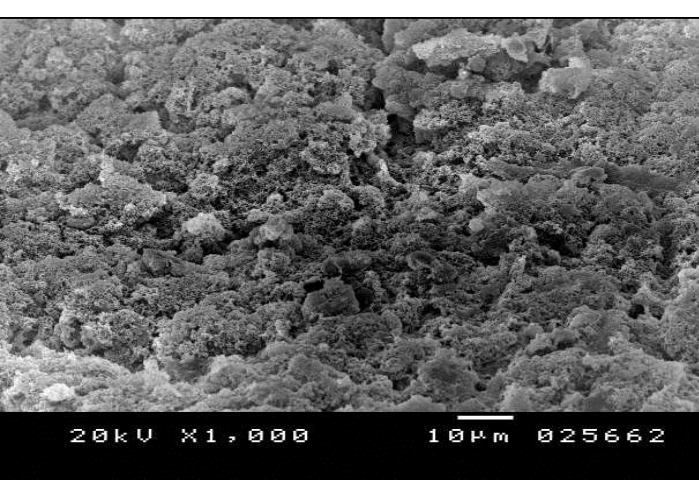

Fig. 5. Scanning electron microscopy photographs $(\times 1000)$ of control non-fat fresh yogurt with pectin

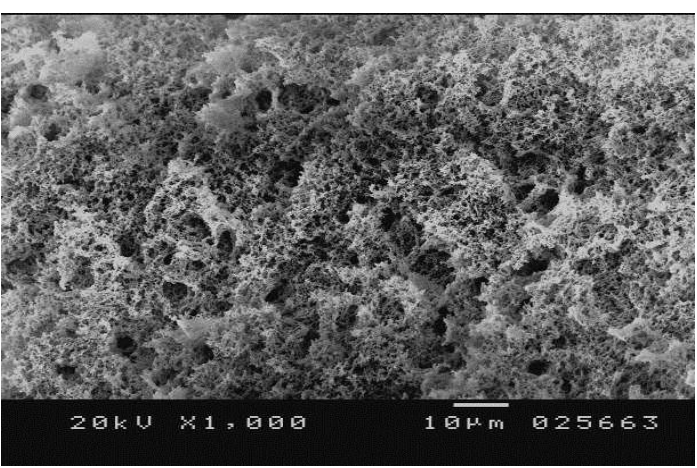

Fig. 6. Scanning electron microscopy photographs $(\times 1000)$ of control non-fat fresh yogurt with gelatin

In comparing between fresh and 10 days old yogurt, we concluded that non-fat control underwent more extensive water

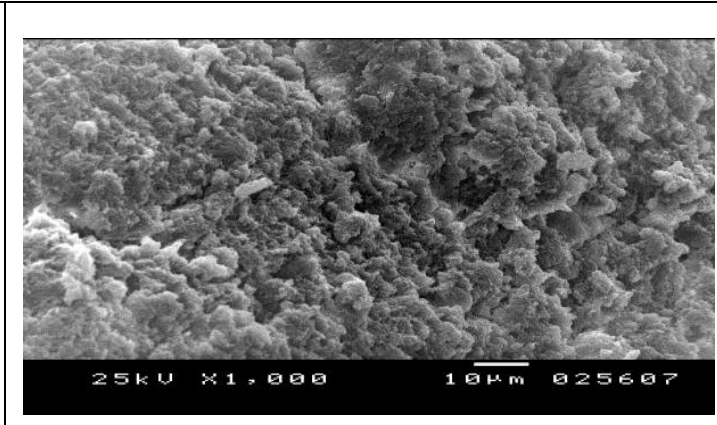

Fig. 4.4. Scanning electron microscopy photographs $(\times 1000)$ of control non-fat yogurt with EPS storage at 10 days.

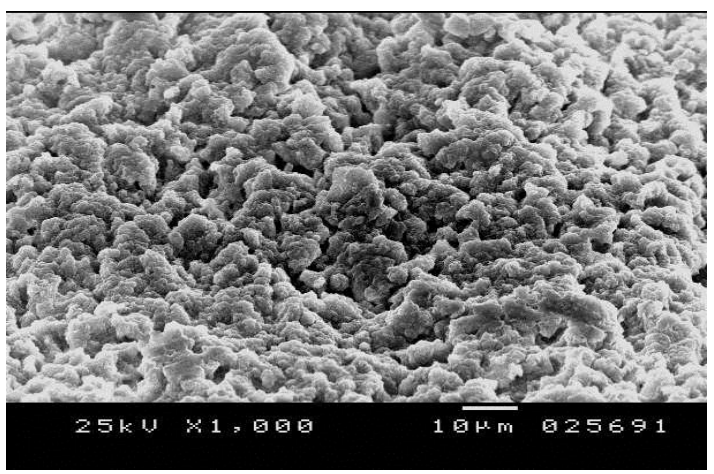

Fig. 5.5 Scanning electron microscopy photographs $(\times 1000)$ of control non-fat yogurt storage at 10 days with pectin

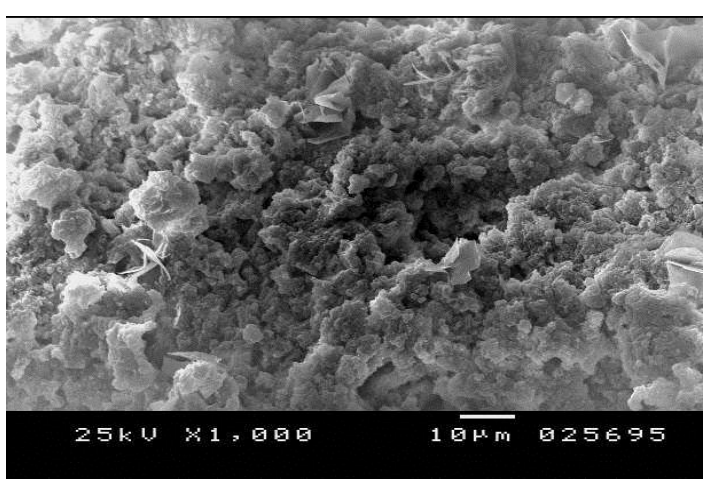

Fig. 6.6. Scanning electron microscopy photographs $(\times 1000)$ of control non-fat yogurt storage at 10days with gelatin

redistribution than non-fat yogurt made with EPS. The electron microscopy micrographs correlated well with the texture analysis 
data. Disturbance of protein-protein interactions and the porosity of the background protein network in the non-fat yogurt seemed to be responsible for the improving the texture properties in these types of yogurt. The microstructure of yogurt has been well studied, and some data have been published on the mechanisms of the acid induction of gels in milk by Streptococcus thermophilus and Lactobacillus delbrueckii subsp. bulgaricus at $30-45^{\circ} \mathrm{C}$. However, the casein micelles are composed of different protein fractions, and are associated with one another via Caphosphate bridges. During the fermentation of milk, the micelle or colloidal $\mathrm{Ca} 2+$ content (and possibly to a lesser extent magnesium and citrate) increases in the serum as the $\mathrm{pH}$ is lowered due to the solubilization of micelle Ca-phosphate (Awad, 2011). Adding textural improvement can affect formation of casein gel structure by acting as filler. Therefore, the effect of textural improvement on protein matrix and structure formation depends on their composition, molecular properties, concentration and interactions with the protein. The appearance of casein micelles were less defined. These differences were probably due to the interactions between casein micelles and stabilizers through mainly hydrophobic interaction leading to the formation of casein stabilizers complexes (Wang et al., 2012). Tamime and Robinson, (1999) reported that, in typical scanning electron micrographs of yogurt with textural improvement, a casein matrix is visible with various forms and sizes of compact area. Scanning electron microscopy (SEM) photographs of fresh skim cow milk yogurt with textural improvement which increases the cohesion flat casein compared with a control sample. The presence of EPS channels in the serum will confer a more polymer-like rheological behavior to the continuous phase, thus resulting in increased consistency index, more deviation from Newtonian behavior, and increased viscosity in the yogurt. The shear-induced microstructure in yogurt made with EPS+ was shown to consist of compartmentalized protein aggregates between channels containing EPS. These EPS containing channels cause yogurt made with EPS+ hindered syneresis and buildup of structure after stirring

\section{Conclusions}

Obtained results suggest possibility of making a good quality low-calorie non-fat yogurt with the use EPS which were similar in quality characteristics to control made with full-fat milk. Also, results indicated that microbial Transglutaminase MTGase mediated cross-linking of milk proteins may be useful method for the production of nonfat yogurt without adversely affecting the affecting the physical properties of the product. It has been shown that cross-linking resulted in improved gel firmness and reduced serum separation in non-fat yogurt. Results also indicated that suitability of using commercial gelatin to improve characterizes of non-fat yogurt. These treatments produced the best quality of nonfat yogurt, besides these trials had low calories and less cost when compared to full fat yogurt and matched the demands of a wide sector of customers. Generally reduction of total solid causes some defects in texture of yogurt, but textural improvement can surmount some of these defects.

\section{Acknowledgements}

The authors would like to thank Mrs. Nour El-Hoda Ahmed for help in texture analysis and moisture determination of the yogurt samples. Thanks are also due to Mrs. Gehan Osman for her help in microbiological analysis.

\section{REFERENCES}

Abd El-Salam, M.H., H.M. EL-Etriby and N. M. Shahein (1996). Influence of some stabilizers on some chemical and physical properties of yogurt. Egyptian J. Dairy Sci. 24:25-36. 
Amatayakul, T., F. Sherkat and N. P. Shah (2006). Physical characteristics of set yogurt made with altered casein to protein rations and EPS-producing starter cultures at 9 and $14 \%$ total solids. Food Hydrocolloids 20: 314-324.

Anema, S.G., S. Lauber, S.K. Lee, T. Henle and $\mathrm{H}$. Klostermeyer (2005). Rheological properties of acid gels prepared from pressure and transglutaminase-treated skim milk. Food Hydrocolloids, 19: 879887.

Anis, S.M.K., E.S. Girgis, S.N. Amer and P.N.M. Salama (1989). Effect of using some stabilizers of yogurt manufacture. Annals of agric. SCi., Moshtohor, 27: 397-406.

A.OA.C. (2000). Official Methods of Analysis. 14th Ed. Association of Official Analytical Chemists. Washington, DC.

Awad, S. (2011). Texture and microstructure: in Practical Food and Research pp. 361-391 (ed. Rui M. S. Cru), Nova Science publishers, Inc.

Bade,I. S., T. Bernardi and P. Michaud (2011). New perspectives for Lactobacilliexopolysaccharides. Biotechnology Advances 29: 54-66.

Barrantes, E., A.M. Sword, G. Davies and M.N. Barclay (1994a). Production of lowcalorie yogurt using skim milk powder and fat-substitutes4: Rheological properties. Milchwissenchaft, 49: 263265.

Bonisch, M.P., M. Huss, K. Weitl and U. Kulozik (2007). Transglutaminase crosslinking of milk proteins and impact on yogurt gel properties. Int. Dairy J. 17: 1360-1371.

Bourne, M.C. (1978). Texture profile analysis. Food Technology. July. 62-72.

Cayot, P. S., F. Cchenker, G. Houze, C. Sulmont-Rosse and B. Colas (2007). Creaminess in relation to consisty and particle size in stirred fat-free yogurt. Int. Dairy J. 18: 303-311.

De Vuyst, L. and B. Degeest (1999). Heteropolysaccharides from lactic acid bacteria. FEMS Microbiology Reviews, 23:153-177.

Dickinson, E. and Y. Yamamoto (1996). Rheology of milk protein gels and protein-stabilized emulsion gels crosslinked with transglutaminase. J. Agric. Food Chem., 44: 1371-1377.

Duboc, P. and B. Mollet (2001). Application of Exopolysaccharides in the dairy industry. Int. Dairy J. 11: 759-768.

Faergemand, M. and K.B. Qvist (1997). Transglutaminase: Effect on rheological properties, microstructure and permeability of set style acid skim milk gel. Food Hydrocolloids, 11:287-292.

Faergamand, M., M. Sorensen, U. Jorgensen, G. Budolfsen and K. B. Qvist (1999). Transglutaminase: effect on instrumental and sensory texture of set style yogurt. Milchwissenschaft, 54: 563-566.

Farag-Seham, I., A. H.El-sonbaty and S.A. Hussein, A.F. Farrag and A.M. Shahine (2007). Effect of substituting added skim milk powder (SMP) with wheat germ (WG) on the quality of goat's milk yogurt and fermented camels milk drink. Proc. 10th Egypt. Conf. Dairy Sci. and technol., 315-336.

Fiszman, S.M., M.A. Luch and A. Salvador (1999). Effect of addition of gelatin on microstructure of acidic milk gels and yogurt and on their rheological properties. Int. Dairy J. 9: 895-901.

Florea, T. and G.M. Costin (2005). Exopolizaharide produse de culturile starter utilizate la fabricarea produselor lactate fermentate. In: Costin, G.M. Ed.Academica, Galati, Italy. p. 421-510.

Folkenberg, D.M. and M. Martens (2003). Sensory properties of low-fat yogurts. Part A: Effect of fat content, fermentation culture and addition of non-fat dry milk on the sensory properties of plain yogurts. Milchwissenchaft, 58: 48-51.

Folkenberg, D.M., P. Dejmek, A. Skliver, H. S. Guldager and R. Ipsen (2006). Sensory and rheological screening of exopolysaccharide producing strains of 
bacterial yogurt cultures. Int. Dairy of J. 16: 111-118.

Gauche, C., T. Tomazi, PLM. Barreto, PJ. Ogliari and MT. Bordignon-Luiz (2009). Physical properties of yogurt manufactured with milk whey and transglutaminase. LWT-Food Sci. Technol, 42: 239-243.

Guzel-Seydim, Z. B., E. Sezgin and A. C. Seydin (2005). Influences of exopolysaccharide producing cultures on the quality of plain set type yogurt. Food Control, 16:205-209.

Hassan, A. N. and J. F. Frank (1997). Modification of microstructure and texture of rennet curd by using a capsule-forming non-ropy lactic culture. J. of Dairy Research, 64: 115-121.

Hassan, A. N., J. F. Frank and M. Elsoda (2003). Observation of bacterialexopolysaccharide in dairy products using cryo-scanning electron microscopy. Int. Dairy J. 13: 755-762.

Hassan, A. N., R. Ipsen, T. Janzen and K.B. Qvist (2003). Microstructure and rheology of yogurt made with cultures differing only in their ability to produce Exopolysaccharides. J. Dairy Sci. 86: 1632.

Hassan, A. N., J. F. Frank, K. A. Schmidt and S.I. Shalabi (1996a). Rheological properties of yogurt made with encapsulated non ropy lactic cultures.J.of Dairy Sci., 70: 2091-2097.

Hess, S. J., R. F. Roberts and G. R. Ziegler (1997). Rheological properties of nonfat yogurt stabilized using Lactobacillus delbrueckii ssp. bulgaricus producing exopolysaccharide orusing commercial stabilizer system. J. ofDairy Sci.80: 252263.

Huyghebaert, A.,K. Dewettinckand W. de Greyt (1996). Fat replacers. In Fat Replacers-Ripening and Quality of Cheese. IDF Bulletin 317:10-15. Brussels: Int. Dairy Federation.

Isanga, J. and G. Zhang (2009). Production and evaluation of some physicochemical parameters of peanut milk yogurt. LWT -
Food Sci. and Technology,42: 11321138.

Jaros, D., M. Jacob, C. Otto and H. Rohm (2010). Excessive cross-linking of caseins by microbial transglutaminase and its impact on physical properties of acidified milk gels. Int. Dairy J. 20: 321327.

Jimenez- Guzman, J.A., A.E. Flores-Najera, Cruz-Guerrero and M. Garcia-Garibay (2009). Use of exopolysaccharideproducing strain of Streptococcus thermophilus in the manufacture of Mexicon panela cheese. LWT-Food Sci. and Technology, 42: 1508-1512.

Keogh, M. K. and B. T. O'Kennedy (1998). Rheology of stirred yogurt as affected by added milk fat, protein and hydrocolloids. J. of Food Sci., 63: 108-112.

Ling, E.R. (1963). A Textbook of Dairy Chemistry. Vol.11, Practical, 3rd Ed., Chapman and Hall, London, UK.

Lee, W. J. and J. A.Lucey (2010) Formation and physical properties ofyogurt.AsianAustralian J. of Animal Sci. 23: 11271136.

Leroux, J., V. Langendorff, G. Schick, V. Vaishnav and R J. Mazoye (2003). Emulsion stabilizing properties of pectin. Food Hydrocolloids, 17: 455-462.

Lorenzen, P. C. and E. Schlimme (1998). Properties and potential fields of application of transglutaminase preparations in dairying, Bulletin. Int. Dairy Federation, Brussels, 33: 47-53.

Lorenzen, PC., H. Neve, R. A. Mautne and E. Schlimme (2002). Effect of enzymatic cross-linking of milk proteins on functional properties of set-style yogurt. Int. J. of Dairy Technology, 55: 152-157.

Lootens, D., F. Capel, D. Durand, T. Nicolai, P. Boulenguer and Langendorff (2003). Influence of $\mathrm{pH}, \mathrm{Ca}$ concentration, temperature and amidation on the gelation of low methoxyl pectin. Food Hydrocolloids, 17: 237-244.

Lucey, J. A., M. Tamehana, H. Singh and P. A. Munro (1999). Stability of model acid milk beverage: effect of pectin 
concentration, storage temperature and milk heat treatment. J. Texture Studies, 30: 305-318.

Maiolino, D. (2002). Functional starches improve mouthfeel in liquid products. National Starch and Chemical Company, Bridgewater, NJ, USA.

Mehanna, N.M., M.E. Ibrahim and I. L. ElNawasany (2013). Impact of some hydrocolloids on the physical characteristics and quality of non-fat yogurt. Egyp. J. Dairy Sci., 41: 163-170.

Mehanna, N.M. and A.S. Mehanna (1989). Study on use of stabilizer for improving some properties of cow's milk yogurt. Egyptian J. Dairy SCI. 17:289-296.

Motoki, M. and K. Seguro (1998). Transglutaminase and its use for food processing. Food Sci. Technol. 9: 204210.

O'Sullivan, MM., AL. Kelly and P. F. Fox (2002). Influence of transglutaminase treatment on some physicochemical properties of milk. J Dairy Res., 69: 433442.

Ozer, B., H. A. Kirmaci, S. Oztekin, A. Hayaloglu and M. Atamer (2007). Incorporation of microbial transglutaminase into non-fat yogurt production. Int. Dairy J. 17: 199-207.

Perry, D. B. and D. J. McMahon (1998). Manufacture of low-fat Mozzarella cheese using EPS-producing culture. J. of Dairy Sci., 81: 563-566.

Perry, D. B., D. J. McMahon and C. J. Oberg (1997). Effect of EPS-producing cultures on moisture retention in low-fat Mozzarella cheese. J. of Dairy Sci., 80: 799-805.

Puvanenthiran, A., R. Williams and $M$. Augustin (2002). Structure and viscoelastic properties of set yogurt with altered casein to whey protein ratios. Int. Dairy J., 12: 383-391.

Saffon, M., V. Richard, R. Jime'nez-Flores, SF. Gauthier, M. Britten and Y. Pouliot (2013). Behavior of heat-denatured whey: buttermilk protein aggregates during the yogurt-making process and their influence on set-type yogurt properties. Foods 2:444-459.

Sandoval - Castilla, O., C. Lobato Callerors,E.Aguirre - Mandujano andR. J.Vernon - Carter (2004).Microstructure and texture of yogurt as influence by fat replacers. Int. Dairy J., 14: 51-159.

Şanlı, T., E. Sezgin, O. Deveci, E. Şenel and M. Benli(2011). Effect of using transglutaminase on physical, chemical and sensory properties of set-type yogurt. Food Hydrocolloids, 25: 14771481.

Sato, Y., S. Kawabuchi, Y. Irimoto and O. Miyawaki (2004). Effect of water activity and solvent-ordering on intermolecular interaction of high-methoxyl pectins in various sugar solutions. Food Hydrocolloids, 18: 527-534.

Shaker, R. R., B. Abu-Jdayil and R.Y. Jumah (2002). Rheological properties of a concentrated fermented product. Labneh, produced from bovine milk: effect of production method. Int. J. of Food properties, 5: 667-679.

Szczesniak, A. S., M. A. Brandtand H. Freidman (1963). Development of standard roting scales for mechanical parameters of texture and correlation between the objective and the sensory methods of texture evaluation. J. of Food Sci., 28: 397-403.

Tamime, A.Y. (2006). Fermented Milks. Blackwell Science Ltd, Oxford, England.

Tamime, A. Y. and R. K.Robinison (1999). Yogurt: Science and Technology, 2 nd ed. Woodhead Publishing Ltd., Cambridge, UK.

Teggatz, J. A. and H. A.Morris (1990). Changes in the rheology and microstructure of ropy yogurt during shearing. Food Structure, 9: 133-138.

Trancoso-Reyes, N., N. Gutiérrez-Méndez, D. R. Sepulveda and L. R.HernándezOchoa (2014). Assessing the Yield, Microstructure, and Texture Properties of Miniature Chihuahua-Type Cheese Manufactured with a Phospholipase A1 
and Exopolysaccharide-Producing Bacteria. J. Dairy Sci.,97: 598-608.

Tsoga, A., R. K. Richardson and E. R. Morris (2004). Role of cosolutes in gelation of high-methoxyl pectin. Part 1. Comparison of sugars and polyols. Food Hydrocolloids, 18: 907-919.

Towler, C. (1984). Sedimentation in a culturesd milk beverage. New Zealand J. of Dairy Sci. and Technology,19: 205211.

Wang, W., Y. Bao, G. Hendricks and M. Guo (2012). Consistency, microstructure and probiotic survivability of goats' milk yogurt using polymerized whey protein as a co-thickening agent. Int. Dairy J., 24, 113-119.

Williams, P. A. and G. O. Phillips (2000). Handbook of Hydrocolloids. Cambridgeand Boca Raton: Woodhead Publishing Limited and CRC Press LLC.
Wosiacki, G. (1977). Enzimas pectinol_iticas de Fusarium oxysporum Schlechtex. Fr. Isolado de frutos de cafe', Thesis. Sa o Paulo, Brasil: Universidade Estadual de Campinas.

Wszolek, M., A.Y. Tamime, D.D. Muir and M.N.I. Barclay (2001). Properties of kefir made in Scotland and Poland using bovine, caprine, and ovine milk with different starter cultures. LebensmittelWissenschaft und-Technologie 34:251261.

Wu, H., G. J. Hulbert and J. R. Mount (2001). Effects of ultrasound on milk homogenization and fermentation with yogurt starter. Innovative Food Science and Emerging Technologies, 1:211-218.

Yazici, F. and A. Akgun (2004). Effect of some protein based fat replacers on physical, chemical, textural, and sensory properties of strained yogurt. J. Food Eng., 62:245-254. 


\title{
تأثير استخدام انزيم الترانس جلوتامينيز الميكرويى ويعض المزارع البكتيريه المنتجه
}

\section{للسكريات العديده كمسنات قوام علي الخواص الطبيعيه والريولوجيه للزيادي خالي الدهن}

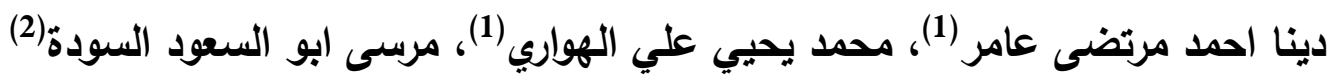

(1) قسم علوم وتكنولوجيا الاغذيه( ألبان). كلية الزراعة جامعة طنطا ملئ

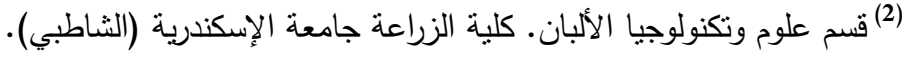

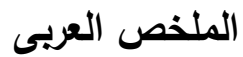

تهدف هذه الدراسة التحسين الخواص الريولوجية والفيزيائية والحسية للزبادى خالى الدسم باستخدام انزيم الترانس

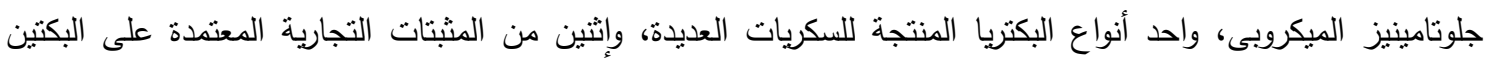

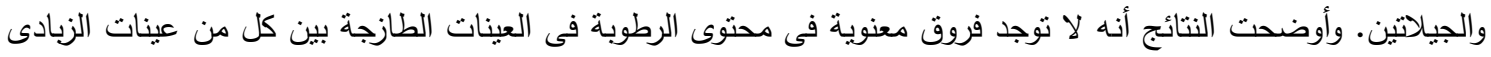

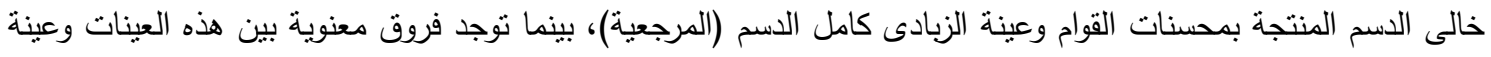

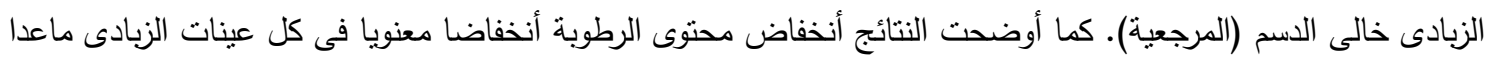

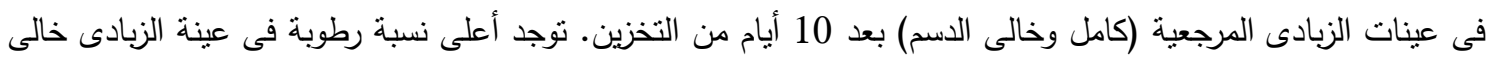

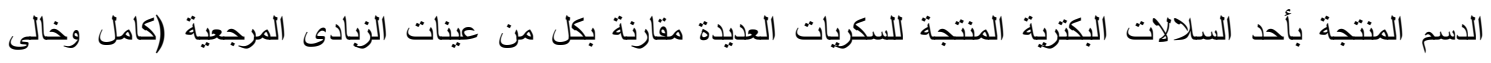

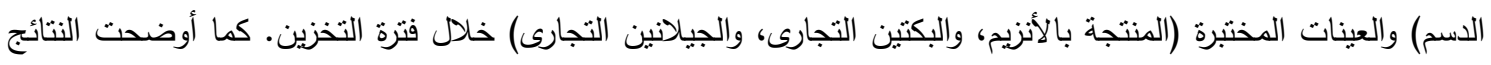

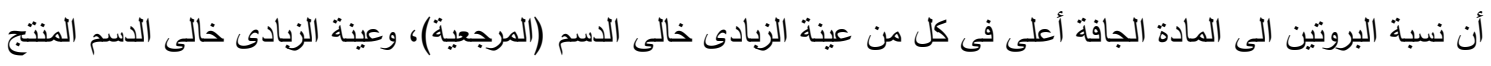

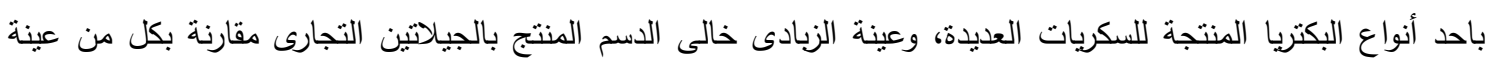

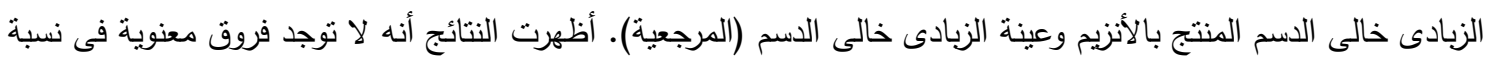

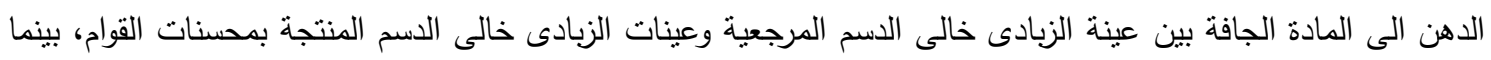

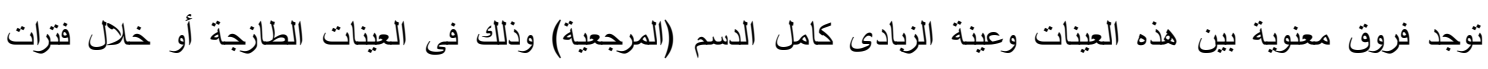

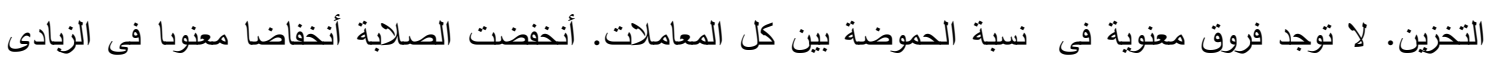

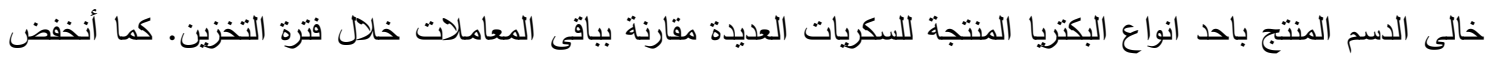

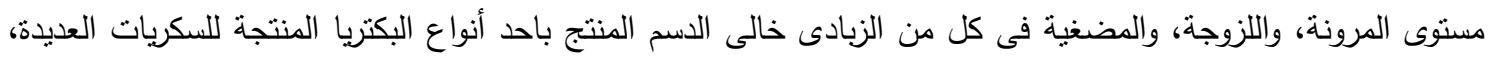

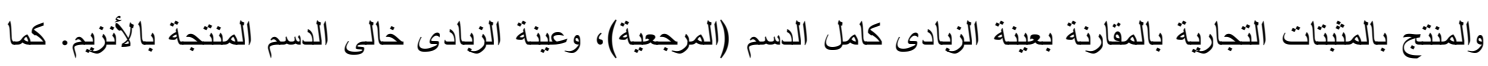

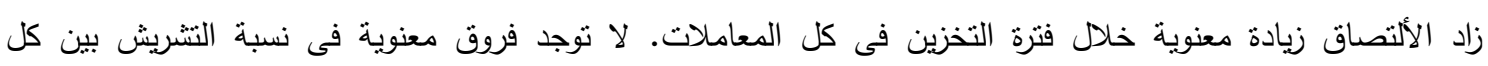

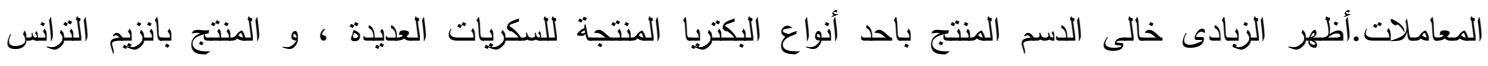
جلوتامينيز الميكروبى وكنلك المنتج بالجلاتين التجارى صفات ريولوجية وطبيعية قريبة للزبادى الكنترول كامل الدسم. 